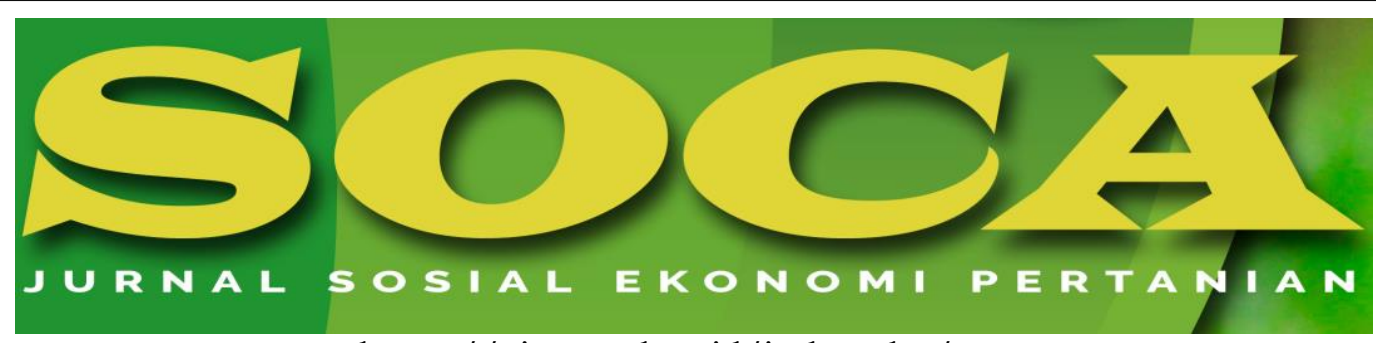

https://ojs.unud.ac.id/index.php/soca

\title{
Green Cayenne Pepper Production and Marketing Collaboration to Increase Farmer's Income In East Lombok Regency, West Nusa Tenggara
}

Yohanes Gili Bulu, Ika Novita Sari, Syvia Kusumaputri Utami and I Putu Cakra Putra Adnyana

Assessment Institute for Agricultural Technology West Nusa Tenggara

Email: yahanesgeli@ymail.com, ikasbw@yahoo.com, Sylvia.utami@ymail.com, putucakra@yahoo.co.id

Handphone: $081933162904,087870759017,081917160128,081915881663$

Submitted: 25 December 2019; Revised: 10 April 2020; Accepted: 17 April 2020

\section{Keywords:} collaboration; production; marketing; income

\begin{abstract}
Abstrak
This study aimed to know: (1) the form of the collaboration done on the green cayenne pepper production and marketing between the farmer and the distributor (2) to analyze the farmer income on the green cayenne pepper production and marketing collaboration. This study was conducted in the central of the cayenne pepper production in East Lombok Regency in March 2017-March 2018. The survey method was employed in this study. The population and participants joined in this study were chosen by the purposive sampling technique. The descriptive analysis was done to merge the quantitative and qualitative analyses used in this study. Results showed that the cayenne pepper production and marketing between the farmer and distributor were productive and able to strengthen their social capital. Technological devices used were also effective in increasing the production of the cayenne pepper as much as IDR 11,343 IDR $\mathrm{kg} / \mathrm{ha}$. The farmer gross income mean was reaching IDR 243,210,000/ha, while the mean of the production cost was IDR 80,040,000/ha, therefore the net income was IDR 163/170,000/ha. The cayenne pepper marketing between the distributors in the West Nusa Tenggara and some regencies in Indonesia was done based on trust and some social norms agreed.
\end{abstract}

How to Cite (APA 6 ${ }^{\text {th }}$ Style):

Bulu, Y. G., Sari, I. N., Utami, S. K., \& Adnyana, I. P. C. P. (2020). Green Cayenne Pepper Production and Marketing Collaboration t o Increase Farmer 's Income In. SOCA: Jurnal Sosial Ekonomi Pertanian, 14(2), 240-252.

https://doi.org/https://doi.org/ 10.24843/SOCA.2020.v14.i02.p05 


\section{INTRODUCTION}

The cayenne pepper is an important commodity demanded in Indonesia. The cayenne pepper was having an important position in agribusiness, especially in the horticultural sector. The cayenne pepper and other vegetable commodities was dominantly produced by farmers with limited fund as their main income. The stable cayenne pepper demand and prices in the domestic market was the major reason for its production and marketing collaboration between the farmer and distributor in the East Lombok Regency.

There is some type of pepper produced in East Lombok Regency: cayenne pepper (green cayenne pepper and white local pepper), red chili, dan curly red chili. East Lombok Regency is the central for the pepper production in West Nusa Tenggara with a total cultivating area of 4.614 ha and total production of 53,342 tons or covering $83.32 \%$ cayenne pepper production in West Nusa Tenggara (West Nusa Tenggara Institute of Statistical Data, 2016). The cayenne pepper cultivating area and the production was increasing significantly until the year 2015, but decreased significantly in 2016 due to the high precipitation level.

The green cayenne pepper cultivating area in East Lombok Regency in 2017 was reaching 5.861 ha with a total production of 843,677 quintal or $84,367.7$ tons. Almost all district in East Lombok was cultivating green cayenne pepper. Suralaga District is a district in East Lombok with the largest green cayenne pepper cultivating land with a size of 2,265 ha, followed by Labuhan Haji District with 952 ha, Selong District with 432 ha, and Jerowaru District with 411 ha cultivating area (East Lombok Institute of Statistical Data, 2017). The amount of green cayenne pepper commodity distributed to outside of West Nusa Tenggara on the January 2016 until May 2017 was as much as 5,809,87 tons (West Nusa Tenggara Agricultural Institute, 2017). The green cayenne pepper was distributed to Bali, Surabaya, Jakarta, West Borneo, Bangka Belitung, Kepulauan Riau and South Sulawesi. The green cayenne pepper was distributed to Jakarta, Surabaya and Bali using land and air transportation, while the distribution to the West Borneo, Bangka Belitung, Kepulauan Riau, and Makasar was done through freight and air transportation.

A stable green cayenne pepper demand and its competing price motivated the farmer to sustainably cultivating the green cayenne pepper and collaborate with the distributor as the owner of the social capital. A collaboration build between the farmer and the distributor/seller in the green cayenne pepper production and marketing was an informal association that arranged based on strong social capital (trust and norm). The social capital was classified into three main components: the network (network collaboration), trust, and norm (Coleman, 1998). The production and marketing collaboration was assumed to be able to provide a stable income and profit. Market availability in promoting the green cayenne pepper can maintain the social capital during the production and marketing collaboration. Coleman (1998) stated that trust is an inherent social capital dimension in social relations and social networks in a society. The relation and social network between the green cayenne pepper farmers were elaborated in the form of production and marketing collaboration which could produce profits to the both of them.

Some issues usually happened in the production and marketing collaboration: (1) significant price fluctuation during the harvesting period, (2) limited farmer fund, 
and (3) limited green cayenne pepper supply. A significant price fluctuation resulted in lower green cayenne pepper price (it could be reached IDR 4,000/kg), which also caused low profit or loss on the farmer party. This study aimed to: 1) know the form of green cayenne pepper production and marketing collaboration; 2) know the farmer income during managing the green cayenne pepper agribusiness.

\section{RESEARCH METHODS}

\section{Approach, Location, and Study Duration}

The survey method was applied in this study to observe the cayenne pepper production and marketing collaboration system in East Lombok Regency, West Nusa Tenggara. The data collection was performed in March 2017 until March 2018.

\section{Study Location and Participant}

The study location was chosen based on the purposive sampling technique. The location selected were Suralaga District and Pringgasela District which having the largest green cayenne pepper cultivation area. The primary data sources were all participants who working as a farmer, distributor on the village area, and distributor on the district area which engaged in the green cayenne pepper production and marketing collaboration. According to the purposive sampling technique used, 15 farmers and 15 distributors were chosen to be interviewed in this study.

\section{Data Type and Data Collection}

The data type collected in this study was the primary data. Data collected from the farmer were the size of the land, type of business, the type and number of production facilities, price and cost for using the production facilities, labors fee, remuneration system and labor's fee for the harvesting period, frequency of the harvesting period, cayenne pepper production, selling price, and marketing cost. While the data collected from the distributor on the village and district area were: the collaboration form and system, type of production facilities used, the amount of loan, duration of load repayment, collaboration rule, and purchasing price. The data was collected through observations, taking transcription notes, and in-depth interviews.

\section{Data Analysis}

To address the study aim, the data analysis approach used was blending between the quantitative and qualitative analysis. The quantitative analysis was supported by the qualitative analysis approach (Taskkori and Teddlie, 1998).

To know the farmer income, an agribusiness cost analysis has to be performed. This type of analysis was using descriptive statistical analysis through a cost calculation during cultivating the green cayenne pepper. The farmer income was equal to the difference between the payment accepted by the farmer and the cost used during cultivating the green cayenne pepper. The payment accepted by the farmer multiplied by the green cayenne pepper production. These could be explained by the formula: $T R=P \times Q$, where $T R=$ payment accepted, $\mathrm{P}=$ price, and $\mathrm{Q}=$ production. The farmer income was calculated using the formula of: PdU = TR - TC, where the $\mathrm{PdU}=$ green cayenne pepper income; TR = the payment accepted, and TC $=$ total cost used during cultivating the green cayenne pepper. 


\section{RESULT AND DISCUSSION}

\section{Green Cayenne Pepper Production and Marketing Collaboration}

The most cayenne pepper farmer in East Lombok regency was having a limited fund for cultivation with the small size of cultivated land of 0.20-0.30 ha. A strategy applied by the farmer to deal with this condition was by cultivating vegetables, especially cayenne pepper which relatively high demanded by the market parties. They assumed that cayenne pepper cultivation was able in producing a high amount of profit which usually ranged between IDR $8,000-12,000 / \mathrm{kg}$. A price disparity also possible to happen if some regions outside the Lombok was in harvesting periods. A high volume of cayenne pepper produced during these harvesting periods caused a significant decrease in its price. The price could reach IDR 4,000/kg which was occurred on the Juni-Juli 2017.

The significant decrease in the cayenne pepper price is affected by the cultivation pattern and the total of cayenne pepper cultivated. Another strategy arranged was to collaborate with the distributor in green cayenne pepper cultivation out of the usual season. But the hindrances in implementing this strategy was the limitation of the capital used to cultivate the cayenne pepper due to the application of plastic mulch and some medications.

Some distributors in Suralaga and Pringgasela was offered the cayenne pepper production and marketing collaboration to the farmers. Collaboration could be defined as an activity conducted in a productive cooperation network that producing benefits in the parties. The cayenne pepper production and marketing collaboration was could be classified into a productive economic collaboration between the distributor and the farmer. Through this collaboration a distributor could provide a fund for cayenne pepper cultivation to 50-100 farmers. A distributor also providing or done a nursery of the cayenne pepper seed. The form of collaboration was: capital loan without interest for the production facilities, supporting devices (medications, fertilizer, pepper seed, plastic mulch), and labors' fee with the total of IDR 3,000,000$5,500.000$ or depended on the need and the total of land cultivated by the farmer. This type of collaboration is also named as supply chain management (SCM) is able in improving the efficiency and level of competitiveness and a sustainable production (Lokollo 2012; Anwarudin, et al, 2015). A sustainable cayenne pepper production is also required a reinforcement that could be done through the implementation of the cultivation calendar. Silmi and Lindawati (2015) stated that the improvement of the production volume using the cultivation calendar would assure the production sustainability and competitiveness.

Table 1. The type of production facilities given and the amount of loan provided by the distributor to the farmer with the size of cultivation land of 0,30 ha.

\begin{tabular}{ccccc}
\hline $\begin{array}{c}\text { Facilities Given by the } \\
\text { Distributor }\end{array}$ & $\begin{array}{c}\text { Unit (kg, } \\
\text { bottle, roll) }\end{array}$ & $\begin{array}{c}\text { Price/Unit } \\
\text { (IDR/unit) }\end{array}$ & $\begin{array}{c}\text { Total } \\
\text { (Rp) }\end{array}$ & Note \\
\hline $\begin{array}{c}\text { Green Cayenne Pepper } \\
\text { (seed) }\end{array}$ & 5,000 & 150 & 750,000 & $\begin{array}{c}\text { The amount of } \\
\text { loan was paid } \\
\text { during the } \\
\text { harvesting } \\
\text { period }\end{array}$ \\
$\begin{array}{c}\text { Fertilizer (urea and NPK) } \\
(\mathrm{kg}) \quad 250\end{array}$ & 2,300 & 575,000 & & \\
$\quad$ Medication (bottle) & 5 & 40,000 & 200,000 &
\end{tabular}




\begin{tabular}{ccr} 
Plastic Mulch (roll) & 5 & 590,000 \\
Labors Fee & $2,950,000$ \\
$1,000,000$ \\
\hline Total & $5,475,000$ \\
\hline
\end{tabular}

Source: Primary Data Analysis, 2018

The cayenne pepper production and marketing collaboration conducted based on trust and social norms agreed by both parties. The distributor was providing facilities during the cayenne pepper production in the form of money and production facilities. A Study done by Ferry and Hidayata (2016) found that if the farmer fail to produce the cayenne pepper, the distributor will not asking the farmer to give the money back. A collaboration created by a strong social capital would improve the social relation between the farmer and the distributor. Furthermore, the strong social capital in the also could improve productivity and maintain an agricultural business. Cahyono (2014) stated that trust and support originally existed on the villagers as their social capital. Similiar with this finding, Anggita (2013) stated that trust and norm in social capital is an important component in supporting a social relationship. Putnam (1995) explained that the social capital refers to three components: (1) social network for communication and coordination, (2) trust, and (3) norm for social regularity in a group of people. Trust is the most important component that contributed to strengthening the sustainable production and marketing collaboration. Collaboration on the social capital concentrating on the social relation between a farmer with some type of group (ex: farmer group institution). Mudiarta (2009) stated that in a collaboration, the social relation was tied by a trust, while the trust was tied by the social norms.

After the harvesting period, the farmer must sell the cayenne peppers to the distributor who was giving them the fund to cultivate the cayenne peppers. The price was set according to the price decided by the seller in the Kramat Jati Jakarta market, Batam, and other provinces in Indonesia. The loan was paid by the farmer slowly during the harvesting period.

\section{The Green Cayenne Pepper Payment Accepted (Reception) Analysis}

The cayenne pepper production in East Lombok, West Nusa Tenggara was still categorized in a low-level production because only reach 11.34 ton/ha (Table 2). The declining on the cayenne pepper production happened due to some factors: 1) pest attack during the rainy season; 2); low level of soil fertility rate; and 3) the low quality of cayenne pepper seed provided by agricultural distributor.

The total payment accepted by the farmer was the result of the production volume multiplied by the selling price (Soekartawi, 2002). Permadi, et al (2017) defined that payment accepted by the farmer was the amount of cayenne pepper produced multiplied by the price on the farmer level. The payment accepted (reception) was the gross income accepted by the farmer according to the harvesting frequency. In each harvesting period, the cayenne pepper price was declining as shown in Table 2. The price kept declining because the selling price in Kramat Jati Jakarta was also declining. This could be happened due to the high volume of cayenne pepper transferred from some regions in Indonesia.

The highest cayenne pepper price in East Lombok, West Nusa Tenggara happened on the first until the fourth/fifth week of February until the fourth week of March 2017. The mean of the farmer gross income in the rainy season (early February) until June 2017 was IDR 243,210,000/ha. 
Table 2. Green Cayenne Pepper Production and Price According to the Harvesting Frequency in East Lombok Regency, West Nusa Tenggara Province

\begin{tabular}{ccccc}
\hline Description & Production & Unit & $\begin{array}{c}\text { Pepper Price } \\
\text { (Rp/ kg) }\end{array}$ & Total (Rp) \\
\hline $\begin{array}{c}\text { The...Harvesting } \\
\text { Period }\end{array}$ & 11,343 & $\mathrm{Kg}$ & & $243,210,000$ \\
$1^{\text {st }}$ & 833 & $\mathrm{Kg}$ & 30,000 & $25,000,000$ \\
$2^{\text {nd }}$ & 1,267 & $\mathrm{Kg}$ & 28,000 & $35,466,667$ \\
$3^{\text {rd }}$ & 1,867 & $\mathrm{Kg}$ & 27,000 & $50,400,000$ \\
$4^{\text {th }}$ & 2,400 & $\mathrm{Kg}$ & 25,000 & $60,000,000$ \\
$5^{\text {th }}$ & 1,567 & $\mathrm{Kg}$ & 23,000 & $36,033,333$ \\
$6^{\text {th }}$ & 900 & $\mathrm{Kg}$ & 18,000 & $16,200,000$ \\
$7^{\text {th }}$ & 600 & $\mathrm{Kg}$ & 15,000 & 9.000 .000 \\
$8^{\text {th }}$ & 333 & $\mathrm{Kg}$ & 12,000 & $4,000,000$ \\
$9^{\text {th }}$ & 307 & $\mathrm{Kg}$ & 7,000 & $2,146,667$ \\
$1^{\text {th }}$ & 283 & $\mathrm{Kg}$ & 4,000 & $1,133,333$ \\
$1^{\text {st }}$ & 253 & $\mathrm{Kg}$ & 4,000 & $1,013,333$ \\
$1^{\text {nd }}$ & 167 & $\mathrm{Kg}$ & 4,000 & 666,667 \\
$1^{\text {td }}$ & 117 & $\mathrm{Kg}$ & 4,000 & 466,667 \\
$1^{\text {th }}$ & 217 & $\mathrm{Kg}$ & 4,000 & 866,667 \\
$1^{\text {th }}$ & 233 & $\mathrm{Kg}$ & 3,500 & 816,667 \\
\hline Gross Income & 11,343 & $\mathrm{Kg}$ & & 243.210 .000 \\
\hline
\end{tabular}

Source : Primary Data Analysis, 2018

\section{Production Cost Analysis}

The production cost is the use of the production facilities, labors fee, and other costs for the production of a certain commodity. The agribusiness cost was the total of value spent by the farmer during the production process that included facilities production cost, the cost spending to buy agricultural devices, and labors fee. Istiyanti et al., (2015) classified the production cost into two types: (1) implicit cost production, non-real amount of cost used by the farmer during the production, and (2) explicit cos production real amount cost use by the farmer during the production.

Cost analysis used to calculate the amount of profit and income obtained by the farmer. The fee paid to the family who was working as the labor paid based on the standard of the remuneration used in the East Lombok. In this study, some production costs: production procurement cost, some supporting fund, labors fee before and during the harvesting period. The labor fee before the harvesting period is paid per day based on the working duration, while labor's fee during the harvesting period was paid according to the harvesting volume production and the cayenne pepper price set during that period.

\section{Production Facilities Cost}

The production facilities cost used in managing the cayenne pepper is quite high. The procurement cost for the production facilities consisted of seed purchasing cost, fertilizer procurement cost, and medication procurement cost with the total of IDR $11,916,667 /$ ha (Table 3). Production facilities were the main factor that must be existed during the production process. Production facilities used closely related to the technological components used in the cayenne pepper production. The amount 
and type of the production facilities used in the cayenne pepper production was arranged according to the components and technological elements used by the farmer, such as the use of NPK fertilizer, SP 6 fertilizer, organic fertilizer, and PPC fertilizer which reached IDR $6,133,333$ /ha or covering $51.47 \%$ from the total of production facilities cost.

Table 3. The Mean Green Cayenne Pepper Production Facilities Cost

\begin{tabular}{|c|c|c|c|c|c|}
\hline Description & Number & Unit & $\begin{array}{c}\text { Price/Uni } \\
\text { t (Rp) }\end{array}$ & Total (Rp) & $\begin{array}{c}\text { Percentage } \\
(\%)\end{array}$ \\
\hline \multicolumn{6}{|l|}{$\begin{array}{l}\text { Production } \\
\text { Facilities Cost }\end{array}$} \\
\hline Seed & & & & $1,750,000$ & 14.69 \\
\hline Seedling & 10,00 & Package & 75,000 & 750,000 & 6.29 \\
\hline $\begin{array}{l}\text { Purchasing the } \\
\text { seed }\end{array}$ & $6,666.67$ & Seed & 150 & $1,000,000$ & 8.39 \\
\hline Fertilizer & & & & $6,133,333$ & 51.47 \\
\hline NPK & 666.67 & $\mathrm{Kg}$ & 2,500 & $1,666,667$ & 13.99 \\
\hline SP 36 & 666.67 & $\mathrm{Kg}$ & 2,500 & $1,666,667$ & 13.99 \\
\hline Liquid Fertilizer & 13.33 & $\mathrm{Kg}$ & 35,000 & 466,667 & 3.92 \\
\hline Organic & 66.67 & Sack & 35,000 & $2,333,333$ & 19.58 \\
\hline Medication & & & & $4,033,333$ & 33.85 \\
\hline Dolomit & $1,666.67$ & $\mathrm{Kg}$ & 1,100 & $1,833,333$ & 15.38 \\
\hline Fungicide & 16.67 & $\mathrm{Kg}$ & 75,000 & $1,250,000$ & 10.49 \\
\hline Amistartop & 3.33 & Bottle & 85,000 & 283,333 & 2.38 \\
\hline Abasel & 3.33 & Bottle & 90,000 & 300,000 & 2.52 \\
\hline Antracol & 3.33 & $\mathrm{~kg}$ & 110,000 & 366,667 & 3.08 \\
\hline Total & & & & $11,916,667$ & 100.00 \\
\hline
\end{tabular}

The medication procurement cost was the main cost allocated by the farmer in the production facilities cost. This medication procurement cost covering $33.85 \%$ of the total production facilities cost.

\section{Supporting Fund and Other Funds}

Supporting funds used in the cayenne pepper production was including the procurement of some tools such as a pole, plastic rope, plastic mulch, and plastic sack. The total of funds used on the supporting production requirements was higher than the production facilities fund that able to reach IDR 15,380,000/ha (Table 4). In one hectare, 20 rolls of good quality plastic mulches were required. Some rolls also could be used in the next harvesting period.

Table 4. The Supporting Fund and Other Funds Used during the Production Process

\begin{tabular}{lccccc}
\hline \multicolumn{1}{c}{ Description } & $\begin{array}{c}\text { Number/ } \\
\text { Amount }\end{array}$ & Unit & $\begin{array}{c}\text { Price per } \\
\text { unit (Rp) }\end{array}$ & $\begin{array}{c}\text { Total } \\
\text { (Rp) }\end{array}$ & $\begin{array}{c}\text { Percentage } \\
\text { (\%) }\end{array}$ \\
\hline Supporting Fund & & & & $\mathbf{1 5 , 3 8 0 , 0 0 0}$ & $\mathbf{7 1 . 2 1}$ \\
Pole & 83.33 & bundle & 35,000 & $2,916,667$ & 13.51 \\
Plastic Rope & 6.67 & $\mathrm{~kg}$ & 12,000 & 80,000 & 0.37 \\
Plastic Mulch & 20.00 & roll & 590,000 & $11,800,000$ & 54.64
\end{tabular}




\begin{tabular}{lccccc} 
Plastic Sack & 166.67 & sheet & 3,500 & 583,333 & 2.70 \\
Other Funds & & & & $\mathbf{6 , 2 1 6 , 6 6 7}$ & 28.79 \\
Food & $1,043.33$ & labor & 5,000 & $5,216,667$ & 24.15 \\
Cigarrete/Coffee & & & & 666,667 & 3.09 \\
Snacks & & & 333,333 & 1.54 \\
\hline \multicolumn{1}{c}{ Total } & & & & $\mathbf{2 1 , 5 9 6 , 6 6 7}$ & 100.00 \\
\hline
\end{tabular}

Source : Primary Data Analysis, 2018

Other funds used to support the cayenne pepper production included some of the supporting requirements such as food, drink, cigarette, and snack with a total of IDR 6,216,667/ha (Table 5). The limited human resources before and during the harvesting period was the major reason for the farmer in providing food and drink for the labor. Food and drink provided by the farmer were capable of decreasing the chance of the labor on moving to another farmer before and during the cayenne pepper harvesting period.

\section{Labor Remuneration before Harvesting Period}

The labor remuneration before the harvesting period was the amount of cost paid since the land preparation until the implementation of integrated pest management. All type of work before the harvesting period such as land preparation, land clearance, tillage, mound making, the dolomite administration, the installation of plastic mulch, the installation of the planting hole, the installation of pole, cultivation, fertilization, weeding, stitching, and its pest management was paid per day. The amount of fee paid by the farmer before the harvesting period was IDR $70.000 /$ day for each labor. But, the laborers were mostly working for 4-5 hours/day, therefore they only paid for Rp IDR 35.000/day. The labor usually working from 07.00 am until $12.00 \mathrm{pm}$ or from 1.00 p.m or $5.00 \mathrm{pm}$.

The amount of cost for the labor before the harvesting period was similar to the cost spent during the harvesting period. The cost was quite high as shown in Table 5 (IDR 22,866,667/ha). Some activities that spent a lot of cost were tillage, the mound making, plastic mulch installation, cultivation, weeding, and fertilization.

Table 5. The Mean of Labor's Fee before the Cayenne Pepper Harvesting Period

\begin{tabular}{|c|c|c|c|c|c|}
\hline Description & Quantity & Unit & $\begin{array}{l}\text { Price per } \\
\text { Unit (Rp) }\end{array}$ & $\begin{array}{l}\text { Total } \\
\text { (Rp) }\end{array}$ & $\begin{array}{c}\text { Percentage } \\
(\%)\end{array}$ \\
\hline \multicolumn{6}{|l|}{$\begin{array}{l}\text { Labor's Fee Before the } \\
\text { Cayenne Pepper Harvesting }\end{array}$} \\
\hline Period & & & & & \\
\hline Land Preparation & 6.67 & Per day & 35,000 & 233,333 & 1.02 \\
\hline Land Clearance & 13.33 & Per day & 35,000 & 466,667 & 2.04 \\
\hline Tillage (using tractor) & 166.67 & Per day & 12,000 & $2,000,000$ & 8.75 \\
\hline Making the mound & 160.00 & Per day & 35,000 & $5,600,000$ & 24.49 \\
\hline $\begin{array}{l}\text { The administration of } \\
\text { dolomit }\end{array}$ & 6.67 & Per day & 35,000 & 233,333 & 1.02 \\
\hline $\begin{array}{l}\text { Installation of plastic } \\
\text { mulchs }\end{array}$ & 166.67 & Per day & 20,000 & $3,333,333$ & 14.58 \\
\hline Making the planting hole & 10.00 & Per day & 40,000 & 400,000 & 1.75 \\
\hline $\begin{array}{l}\text { Installation of the pole and } \\
\text { plastic rope }\end{array}$ & 13.33 & Per day & 70,000 & 933,333 & 4.08 \\
\hline $\begin{array}{l}\text { Cultivation } \\
\text { Basic Fertilization }\end{array}$ & 93.33 & Per day & 35,000 & $\begin{array}{l}3,266,667 \\
1,866,667\end{array}$ & $\begin{array}{c}14.29 \\
8.16\end{array}$ \\
\hline
\end{tabular}




\begin{tabular}{|c|c|c|c|c|c|}
\hline Pemupukan dasar & 13.33 & Per day & 35,000 & 466,667 & 2.04 \\
\hline Liquid Fertilization & 20.00 & Per day & 35,000 & 700,000 & 3.06 \\
\hline NPK Fertilization & 10.00 & Per day & 35,000 & 350,000 & 1.53 \\
\hline TSP Fertilization & 10.00 & Per day & 35,000 & 350,000 & 1.53 \\
\hline Weeding: & & & & $3,733,333$ & 16.33 \\
\hline $1^{\text {st }}$ Weeding & 26.67 & Per day & 35,000 & 933,333 & 4.08 \\
\hline $2^{\text {nd }}$ Weeding & 26.67 & Per day & 35,000 & 933,333 & 4.08 \\
\hline $3^{\text {rd }}$ Weeding & 26.67 & Per day & 35,000 & 933,333 & 4.08 \\
\hline $4^{\text {th }}$ Weeding & 26.67 & Per day & 35,000 & 933,333 & 4.08 \\
\hline Stitching: & & & & 700,000 & 3.06 \\
\hline $1^{\text {st }}$ Stitching: 1000 stems & 6.67 & Per day & 35,000 & 233,333 & 1.02 \\
\hline $2^{\text {nd }}$ Stitching: 600 stems & 6.67 & Per day & 35,000 & 233,333 & 1.02 \\
\hline $3^{\text {rd }}$ Stitching: 300 stems & 3.33 & Per day & 35,000 & 116,667 & 0.51 \\
\hline 4th Stitching: 150 stems & 3.33 & Per day & 35.000 & 116,667 & 0.51 \\
\hline $\begin{array}{l}\text { Integrated Pest } \\
\text { Management }\end{array}$ & & & & 100,000 & 0.44 \\
\hline Total & & & & $22,866,667$ & 100 \\
\hline
\end{tabular}

Source : Primary Data Analysis, 2018

\section{Harvesting Labors Remuneration}

The cayenne pepper harvesting period in a cultivation system was ranged between 10-15 times or once a week. The remuneration system used was different from another commodity agricultural remuneration system. The system used in East Lombok, West Nusa Tenggara was multiplied the volume of cayenne pepper produce with the price percentage as agreed by the farmer and the labor. The mean fee accepted by the labor was ranged between $10 \%-43 \%$ from the cayenne pepper price set during the harvesting period. If the cayenne pepper price decreasing, the labor's fee would increase. It could be illustrated by the cayenne pepper prices on the fourth week in February 2017 which reach IDR 30,000/kg. According to the price, the fee accepted by the labor was $10 \%$ from the cayenne pepper price (IDR 3, 000/kg) which then multiplied by the total cayenne pepper produced on the harvesting period $(833.33 \mathrm{~kg})$, therefore the total of fee accepted by the labor during the harvesting period was IDR 2,500,000 (Table 6).

Table 6. The Cayenne Pepper Number of Labor and Its Remuneration System in East Lombok, West Nusa Tenggara

\begin{tabular}{|c|c|c|c|c|c|c|}
\hline $\begin{array}{c}\text { Description } \\
\text { (The...Harv } \\
\text { esting } \\
\text { Period) }\end{array}$ & $\begin{array}{c}\text { Number } \\
\text { of } \\
\text { Working } \\
\text { (Days) }\end{array}$ & $\begin{array}{c}\text { Price } \\
\text { (Rp/kg) }\end{array}$ & $\begin{array}{c}\text { Fee } \\
\text { (Rp/kg) }\end{array}$ & $\begin{array}{c}\text { Harvesting } \\
\text { Volume } \\
\text { (Kg) }\end{array}$ & $\begin{array}{c}\text { The Total } \\
\text { of } \\
\text { Harvesting } \\
\text { Cost (Rp) }\end{array}$ & $\begin{array}{c}\text { Perce } \\
\text { ntage } \\
(\%)\end{array}$ \\
\hline $1^{\text {st }}$ & 66.67 & 30,000 & 3,000 & 833.33 & $2,500,000$ & 10.57 \\
\hline $2^{\text {nd }}$ & 80.00 & 28,000 & 2,500 & $1,266.67$ & $3,166,667$ & 13.38 \\
\hline $3^{\text {rd }}$ & 80.00 & 27,000 & 2,000 & $1,866.67$ & $3,733,333$ & 15.78 \\
\hline $4^{\text {th }}$ & 80.00 & 25,000 & 2,000 & $2,400.00$ & $4,800,000$ & 20.29 \\
\hline $5^{\text {th }}$ & 60.00 & 23,000 & 2,000 & $1,566.67$ & $3,133.333$ & 13.24 \\
\hline $6^{\text {th }}$ & 53.33 & 18,000 & 2,000 & 900.00 & $1,800,000$ & 7.61 \\
\hline $7^{\text {th }}$ & 46.67 & 15,000 & 2,000 & 600.00 & $1,200,000$ & 5.07 \\
\hline $8^{\text {th }}$ & 43.33 & 12,000 & 2,000 & 333.33 & 666,667 & 2.82 \\
\hline $9^{\text {th }}$ & 43.33 & 7,000 & 2,000 & 306.67 & 613,333 & 2.59 \\
\hline $10^{\text {th }}$ & 33.33 & 4,000 & 2,000 & 283.33 & 566,667 & 2.40 \\
\hline
\end{tabular}




\begin{tabular}{ccccccc}
$11^{\text {st }}$ & 20.00 & 4,000 & 1,500 & 253.33 & 380,000 & 1.61 \\
$12^{\text {nd }}$ & 13.33 & 4,000 & 1,500 & 166.67 & 250,000 & 1.06 \\
$13^{\text {rd }}$ & 6.67 & 4,000 & 1,500 & 116.67 & 175,000 & 0.74 \\
$14^{\text {th }}$ & 6.67 & 4,000 & 1,500 & 216.67 & 325,000 & 1.37 \\
$15^{\text {th }}$ & 6.67 & 3,500 & 1,500 & 233.33 & 350,000 & 1.48 \\
\hline Total & & & & $23,660,000$ & 100 \\
\hline
\end{tabular}

Source : Primary Data Analysis, 2018

\section{Income and Green Cayenne Pepper Profit Analysis}

Agricultural income was defined as the payment for the production and service use during the production process in producing an agricultural commodity. Soekartawi (2006) stated that the income was the difference between the payment and the production cost. An efficiency indicator used was the amount of acceptance for each rupiah used as the payment (revenue cost ratio or $\mathrm{R} / \mathrm{C}$ ratio). The Return Cost $(\mathrm{R} / \mathrm{C})$ ratio analysis is a ratio between the reception and cost (Rahim dan Hastuti, 2008); Husni et al., 2014). This analysis employed to know the relative agribusiness profit based on the financial calculation. $\mathrm{R} / \mathrm{C}$ ratio shows the amount of reception accepted by the farmer in comparison with the cost spent. Soekartawi (2006) stated that $\mathrm{R} / \mathrm{C}$ is a ratio between the reception and cost. The calculation done was found that the $\mathrm{R} / \mathrm{C}$ ratio was 3.04 (Table 7 ) that indicated the green cayenne pepper business is profitable. An addition of IDR 1.0 produces the reception as much as IDR 304.

Table 7. Green Cayenne Pepper Profit in East Lombok Regency, West Nusa Tenggara

\begin{tabular}{|c|c|c|c|c|c|}
\hline Description & $\underset{\text { ty }}{\text { Quanti }}$ & Unit & $\begin{array}{l}\text { Price per } \\
\text { Unit (Rp) }\end{array}$ & Total (Rp) & $\begin{array}{c}\text { Cost } \\
\text { Percentage } \\
(\%) \\
\end{array}$ \\
\hline $\begin{array}{l}\text { Payment Accepted } \\
\text { (Rp/Ha) }\end{array}$ & 11,343 & $\mathrm{Kg}$ & & $243,210,000$ & \\
\hline Biaya (Rp/Ha) & & & & $80,040,000$ & 100.00 \\
\hline $\begin{array}{l}\text { Production } \\
\text { Facilities }\end{array}$ & 1 & paket & $11,916,667$ & $11,916,667$ & 14.89 \\
\hline $\begin{array}{l}\text { Labors who } \\
\text { working before the } \\
\text { Harvesting Period } \\
\text { Labors who }\end{array}$ & 1 & paket & $22,866,667$ & $22,866,667$ & 28.57 \\
\hline $\begin{array}{l}\text { working during the } \\
\text { Harvesting Period }\end{array}$ & 1 & paket & $23,660,000$ & $23,660,000$ & 29.56 \\
\hline Others. & 1 & paket & $21,596,667$ & $21,596,667$ & 26.98 \\
\hline Profit $(\mathrm{Rp} / \mathrm{Ha})$ & & & & & $163,170,000$ \\
\hline R/C Ratio & & & & & 3.04 \\
\hline B/C Ratio & & & & & 2.04 \\
\hline
\end{tabular}

Source : Data Primary Analysis, 2018 


\section{CONCLUSION}

The collaboration on the green cayenne pepper production and marketing between the farmer and the distributor aimed to create a sustainable green cayenne pepper and improving their competitiveness in the marketing aspect. This sustainable collaboration was conducted based on a strong social capital/capital.

The green cayenne pepper price on the farmer level was determined by the price on the distributor level (Kramatjati). The communication between the seller on the market level with the distributor in informing the green cayenne pepper price was the form of collaboration in the marketing aspect.

The green cayenne pepper prices affected the amount of the harvesting volume and its distribution system. The prices usually were higher outside the harvesting period than in the harvesting period.

The profit of the green cayenne pepper was reaching IDR $163,170,000 /$ ha/ harvesting season, which also depends on the pepper prices in the market. The profit was higher outside the harvesting period than in the harvesting period.

The price differences between the farmer and the distributor were IDR $3,650 / \mathrm{kg}$ which could be categorized as normal price differences. It could be higher due to the high cost spent to sell the green cayenne pepper outside Java Island.

\section{RECOMMENDATION}

A sustainable green cayenne pepper production and marketing collaboration still requiring a stronger social relationship and social capital. Support from the government is also demanded in managing the green cayenne pepper's price and its sustainable production and marketing.

\section{REFERENCES}

Anggita Tiara. 2013. Dukungan Modal Sosial dalam Kolektivitas Usaha Tani untuk Mendukung Kinerja Produksi Pertanian (Studi Kasus: Kabupaten Karawang dan Subang). Jurnal Perencanaan Wilayah dan Kota, Vol. 24 No. 3, Desember 2013:.203 - 226 .

Anwarudin, M. Jawal., Apri L. Sayekti, Aditia Marendra K., dan Yusdar Hilman. 2015. Dinamika Produksi dan Volatilitas Harga Cabai: Antisipasi Strategi dan Kebijakan Pengembangan. Pengembangan Inovasi Pertanian Vol. 8 No. 1 Maret 2015: 33-42.

Asrianti Evi. 2014. Analisis Pemasaran Usahatani Cabai Merah kriting di desa Maku Kecamatan Dolo, Kabupaten Sigi.e-JurnalAgrotekbis 2 (6) Desember 2014: 660666.

BPS.2016. Nusa Tenggara barat Dalam Angka. Biro Pusat Statistik Propinsi NTB. Mataram.

Cahyono Budhi. 2014. Peranan Modal Sosial dalam Peningkatan Kesejahteraan Masyarakat Petani Tembakau di Kabupaten Wonosobo. Jurnal EKOBIS Vol.15, No.1, Januari 2014: 1 - 16.

Coleman, J. 1998. Social Capital in the Creation of Human Capital. American Journal of Sociology 94 (Suplement): S95 - S 120. 
Dinas Pertanian dan Perkebunan propinsi NTB.2017. Laporan Bulanan dan Tahunan Dinas Pertanian dan Perkebunan propinsi Nusa Tenggara Barat.Mataram.

Ekawati Budi Utaminingsih, Watemin, dan Dumasari. 2009. Analisis Pemasaran Cabai Merah di desa Gombong, Kecamatan Belik, Kabupaten Pemalang.Jurnal AGRITECH Vol. 11 No. 2, Desember 2009:116 - 124.

Ferry Yulianjaya dan Kliwon Hidayat. 2016. Pola Kemitraan Petani Cabai Dengan Juragan Luar Desa (Studi Kasus Kemitraan di Desa Kucur, Kecamatan Dau, Kabupaten Malang). Jurnal Habitat, Volume 27, No. 1, April 2016: 37-47.

Husni, Abdul Kholik Hidayah, dan Maskan AF, 2014. Analisis Finansial Usahatani Cabai Rawit (Capsicum frutescens $L$ ) di desa Purwajaya, Kecamatan Loa Janan.Jurnal AGRIFOR Volume XIII Nomor 1, Maret 2014: 49 - 52.

Indriani, R., R. Darma, Y. Musa, AN. Tenriawaru, Made Viantika. 2019. Mekanisme Rantai Pasok Cabai Rawit di Propinsi Gorontalo. JSEP, Volume 15, No. 1, Februari 2019: $31-41$

Ikpeme CE, Henry P, Okiri OA. 2014. Comparative evaluation of the nutritional, phytochemical and microbiological quality of three pepper varieties. J Food Nutr Sci 2 (3):74-80.

Istiyanti, Eni, Uswatun Khasanah dan Arifah Anjarwati. 2015.Pengembangan Usahatani Cabai Merah di Lahan Pasir Pantai Kecamatan Temon Kabupaten Kulonprogo.Jurnal AGRARIS Vol. 1 No. 1. 2015: 6 - 12.

Kouassi CK, Koffi-nevry R, Guillaume LY.2012. Profiles of bioactive compounds of some pepper fruit (Capsicum L.) Varieties grown in Côte d'ivoire. Innovative Romanian Food Biotechnol 11: 23-31.

Lokollo, E.M. 2012. Bunga Rampai Rantai Pasok Komoditas Pertanian Indonesia. IPB Press, Bogor.

Mudiarta, Ketut Gede. 2009. Jaringan Sosial (Networks) dalam Pengembangan Sistem Usaha Agribisnis: Perspektif Teori dan Dinamika Studi Kapital Sosial. Jurnal Forum Penelitian Agro Ekonomi.Volume 27 No. 1, Juli 2009. 1 - 29p.

Made Ayu Dessy Dora Agnellia, I. Nyoman Gede Ustriyana, A. A. A. Wulandira Sawitri Djelantik.Analisis Struktur, Perilaku, dan Kinerja Pasar Cabai di Desa Bayung Gede, Kecamatan Kintamani, Kabupaten Bangli. E-Jurnal Agribisnis dan Agrowisata Vol.5, No.1, Januari 2016: 1 - 10.

Mudiarta, Ketut Gede. 2009. Jaringan Sosial (Networks) dalam Pengembangan Sistem Usaha Agribisnis: Perspektif Teori dan Dinamika Studi Kapital Sosial. Jurnal Forum Penelitian Agro Ekonomi. Volume 27 No. 1, Juli 2009: 1 - 29.

Permadi, Galang Ramadhan Putra, Rita Mariati, dan Dina Lesmana. 2017. Analisis Pendapatan Usahatani dan Pemasaran Cabai Rawit (Capsicum frutescens L.) di Kecamatan loa Janan, Kabupaten Kutai Kartanegara. Jurnal Ekonomi Pertanian dan Pembangunan, Volume 14 No. 1, Maret 2017: 33 - 45. 
Prayitno Ariep Budi, Ali Ibrahim Hasyim, Suriaty Situmorang. 2013. Efesiensi Pemasaran Cabai Merah di Kecamatan Adiluwih Kabupaten Pringsewu Propinsi lampung. Jurnal JIIA Volume 1 No. 1, Januari 2013: 52 - 59.

Rahim Abd.dan Diah Retno Dwi Hastuti. 2008. Pengantar, Teori dan Kasus Ekonomika Pertanian. Penebar Swadaya. Jakarta: 204.

Tashakkori, A. dan Ch. Teddlie. 1998. Mixed Methodology, Combining Qulaitative and Quantitative Approaches. SAGE Publications.Thousand Oaks London-New Delhi.

Silmi T. dan Lindawati Kartika. 2015. Kelembagaan dan Strategi Peningkatan Daya Saing Komoditas Cabai di Kabupaten Garut. Jurnal Manajemen \& Agribisnis, Vol. 12 No. 1, Maret 2015. Nomor DOI: 10.17358/JMA.12.1.1: 1-13.

Soekartawi. 2002. Prinsip Dasar Ekonomi Pertanian. Raja Grafindo Persada. Jakarta.

Soekartawi, 2006.Agribisnis Teori dan Aplikasi. Rajawali Press. Jakarta.

Putnam, R. 1995. Bowling Alone: America's Declining Social Capital.Journal of Democracy. 6:65-78. 